\title{
Establishing and navigating the rules of the road in Arctic diplomacy
}

During its 2003-2005 chairmanship of the Arctic Council, Russia - the 'largest' Arctic state - suggested that Arctic cooperation should focus more on the city level. The idea never really garnered any support. This is understandable, on the one hand, in that the idea suited poorly the 'many Arctics' represented by the other countries, most of which include settlements and towns, but very few cities compared to the relatively urbanised Russian Arctic (Orttung, 2017). The urban Arctic also corresponded poorly with dominant framings of the Arctic as a wild and sparsely populated landscape (see Chapter 2).

On the other hand, it is a bit surprising, in that Russia is decidedly the largest Arctic state and the country's involvement was seen as essential to securing effective circumpolar cooperation, as we have seen in Chapter 3. There are few other examples of proposed project ideas in the Arctic Council falling between the cracks publicly as this did. However, if we fast-forward to 2017, Russia has since successfully co-chaired the three binding agreements negotiated formally outside the Arctic Council, but in close conversation and celebration with the forum.

So, why did some of the earlier suggestions and interests of the largest' Arctic state fail to carry more weight in this Arctic diplomatic setting? This chapter suggests that such failed or drifting ideas give us a good indication of the impact of norms - shared understandings of appropriate and inappropriate interventions and behaviour - in shaping what is accepted as a legitimate statement or policy option in the Arctic Council. Understanding the ways in which norms exert influence over behaviour in cross-border relations requires reconceptualising the space of global governance as more than a dynamic, inclusive, vast network of governance. Rather, we need to consider how delimited and 'local' the meeting places of cross-border politics - what we can term global governance policy fields - frequently become. 
This chapter examines Russia's engagement in the Arctic Council over time to see how its preferences are met (or not), and discusses what this can tell us about the rules of the road in cross-border Arctic diplomacy. Acknowledging that performances of power - including developing and enforcing norms - have an inherently 'local' aspect is important to grounding broad statements about power in global governance. The proposition about power relations here is that Arctic cross-border cooperation plays out in an environment that has social constraints and norms. These constraints allow for the performance of Arctic diplomacy to a more, or less, successful degree, and shape behaviour, even of the 'great powers', in the region.

In the first section, we revisit the notion of policy fields to conceptualise how the sporadic meeting places of global governance can indeed become imbued with a site-specific social thickness that matters for shaping behaviour. We then turn to the long lines of Russia's approach to the Arctic, as context for the interventions of Russia's policymakers and diplomatic representatives in Arctic cross-border relations. Some of Russia's key interventions in the politics of the Arctic Council in two separate periods, 1997-2007 and 2007/08-2017, are analysed, based on interviews and Arctic Council archives. This periodisation is chosen as two equally long periods of time - a decade of Arctic diplomacy each. The two periods are also punctuated by key political events in Arctic politics (the Ilullissat Declaration of 2008) and Russian foreign policy (Putin's speech in Munich asserting Russia's return to global power politics). The chapter concludes with a discussion of what Russia's successful and failed interventions tell us about the evolving norms of Arctic cross-border governance - and how Russia has played a role in developing them.

\section{Norms of belonging, speaking and acting}

The architecture of acceptable and unacceptable State action in the Arctic is secured in hard and soft laws, such as the UN Convention on the Law of the Sea, and also global conventions on other issues relating to biodiversity, trade, the Polar Code of the International Maritime Organization and so on. Compliance with these rules is often optional and sometimes binding, but, in any case, the content of the rules tends to be developed through formal political processes of negotiation (at the international level). These rules also tend to be anchored to varying degrees at the domestic level, such as through ratification processes for hard law or through involvement of domestic stakeholders in formulating a country's negotiating position for a soft-law process.

However, a good deal of Arctic politics - and governance-development takes place outside such formal strictures - and informal diplomacy is 
often highly important in bringing a policy problem to the formal negotiating table. For example, at the Arctic Council, there are indeed formal procedures for submitting an issue as an agenda item, but if and how proposed issues survive and thrive has much to do with the proposer's position and standing, skills of persuasion and identification of mutual interest, and calling in favours. Overt demonstrations of dominance, as discussed in the preceding chapter, are rare. Rather, the Arctic, and also broader global governance forums in which the Arctic's governance actors are enmeshed, are criss-crossed by norms. These norms may have been promoted by the powerful and adopted by the weak, or generated cooperatively and gradually as certain modes of behaviour are recognised by multiple players in politics as a good match for the social structure of a given field (Bernstein, 2001). In this perspective, norms are best understood as empirical outcomes of many interactions - rather than exhortations or obvious rules (Bernstein, 2001: 467; Finnemore and Sikkink, 1998)

So, how do we get at the practices, norms and relations of power that shape the rules of the road in Arctic cross-border politics in less obvious ways? As discussed in preceding chapters, I suggest that we get important analytical purchase from scholarly work in IR on the idea of policy 'fields'. The notion of a policy 'field' draws upon Bourdieu's work, which defines a field as delineating a realm of interaction with internal rules about appropriate behaviour. Applying this concept from sociology to IR helps us envision the space of global politics as delimited and productive of political culture - shared expectations, shared norms of behaviour and shared framings of/discourses around policy objects.

Sending (2015) argues that fields in global politics should be understood as organised around different objects of governance about which actors can hold differing conceptions. What unites them is a 'thin' interest in what is at stake and (more or less) agreed-upon ways of approaching the problem. This is to say that experts may not share the same 'identity' or 'discourse', but rather come together over a shared interest in addressing old or new policy problems. However, over time, policy field participants can establish (or borrow from related fields) a variety of social rules beyond the basic agreement to meet around a particular policy object. They will, therefore, be able to identify, and may react to others' departures from, these well-worn pathways of political participation. To take an example from global climate negotiations, we see that negotiators sent to represent their Government's opinion are also expected to contribute more generally to moving discussions forward in their specific areas of expertise (for example, land use or carbon accounting), regardless of whether this is of direct importance to their country's specified national interests (Wilson Rowe, 2013d). 
Of course, as discussed in Chapter 3, not all actors (professional networks, interest-based organisations, state representatives, business representatives) involved in global governance will be equally well positioned to 'play the game'. Agents in a field occupy unequal positions, and control over relevant economic, social and symbolic resources is usually unevenly distributed, causing various 'player[s] to play the game more or less successfully' (Pouliot, 2010: 34). We will return to this discussion of the informal norms and uneven terrain of Arctic governance in the final section. First, we consider the kinds of resources, policy traditions and political concerns Russia has brought to the cross-border governance table from its own domestic Arctic.

\section{A large part of many different 'Norths': the Russian Arctic}

A key emphasis that is now regularly reiterated by Arctic states is that the Arctic is actually 'many Arctics'. Canadian representatives at conferences in the European Arctic frequently emphasise the remoteness and sparse population of the Canadian Arctic, as a contrast to the relatively highly populated and interconnected reaches of the Nordic Arctic. Russia too has long sought to gain purchase in multilateral settings for its own Arctic specificities - a unique combination of resource-rich, sparsely populated and comparatively highly urbanised (Josephson, 2014; Krivorotov, 2015; Sergunin and Konyshev, 2015). In this section, we take a cue from the actual field participants who point to these many Arctics and first dedicate attention to understanding the long lines of Russia's engagement with its own Arctic, before turning to how the country has intervened in multilateral circumpolar diplomacy.

In today's Russian Arctic, I would argue that there are four main tensions or balancing acts that characterise Russian policymaking around development questions (for an extended discussion, see Wilson Rowe, 2017a). First, there is a tension between traditions of, and continued need for, large State subsidies of Arctic infrastructure and social services, and the desire to have the Arctic primarily as a source of profit for the entire country. Russia inherited from the Soviet Union a North ill-suited to the demands and logic of the market economy. Russian northern policy during the transitional 1990s could be described as haphazard, and focused primarily on emergency measures to alleviate acute fuel and supply shortages, attempting to respond to economic and social crisis in the region. Some areas (Chukotka, for example) experienced conditions of humanitarian crisis, necessitating the involvement of organisations such as the Red Cross (Thompson, 2009). As Helge Blakkisrud (2006) argues in his comprehensive study of Russia's northern policy through the first Putin term, a key aspiration of Arctic policy was to draw a 
distinction between the 'profitable North' and the 'unprofitable North'. The 'profitable North' - the areas rich in oil and gas and minerals - was to be further developed. The 'unprofitable' North - areas dependent on federal support and without prospects for viable economic activity - was slated to be scaled down, and the non-indigenous population encouraged to resettle. As Lagutina (2013) notes, however, the debate long continued as to how to strike the right balance between State-led, subsidised development and a market-principles-only approach to regional development.

The region's natural resource wealth made the aim of income generation a realisable pursuit - to some extent. The Arctic produces about one-tenth of the world's crude oil and a quarter of its gas. Of this output, 80 per cent of the oil and 99 per cent of the gas come from Russia (AMAP, 2007). However, there are limits to a market-driven development of the North that continuously raise the issue of subsidies versus market mechanisms and private investment. This tension is one that some of the strategy documents presented below address directly and is particularly prominent in large infrastructure projects, such as the rejuvenation of ports along the Northern Sea Route or renewal of the icebreaking fleet (Moe, 2014). The emphasis on shift work (fly-in/fly-out labour) for new sources of natural resource wealth is an indication of this balancing act - pursuing regional profit without committing to the development of social infrastructure (Laruelle, 2013; Saxinger, Nuykina and Ofner, 2017).

A second issue is the locus of decision-making power. Putin's recentralisation of power from the regions to the federal level contrasted sharply with the widespread decentralisation of the 1990s. Moscow, rather than Magadan or Murmansk, now governs this vast territory. At the same time, the cooperation of regional governors is essential for implementing federal policies in far-flung regions of Russia; they are often called upon to front Arctic efforts publicly and, thereby, are likely to exert some behind-the-scenes influence (Sergunin and Konyshev, 2015: 5978). It is also important to note that centralisation can be understood too as a consolidation of power into the halls of government - and away from civil society. This has consequences, for example, in the Russian indigenous peoples' association RAIPON's participation in Arctic crossborder governance (see Chapter 4).

A third balancing act - between an 'open' and 'closed' Arctic - also characterises the region. Specifically, Russia's evolving relationship to its North entails a tension between the securitisation of northern space and the nationalisation of northern resources working against more international and market-driven orientations (Wilson Rowe, 2009; Baev, 2013). For example, Soviet Arctic industrial cities - in particular those associated with the military complex - were among the more closed places in the Soviet space, requiring special and closely controlled 
registration permits even for Soviet citizens. At the same time, the natural resources around which many of these cities were built were subject to global affairs and commodity markets, leaving them vulnerable to the vagaries of international politics and price swings.

Marlene Laruelle, in her comprehensive book on the Russian North, describes a similar tension, coining it as one between a 'security first' and a 'cooperation/economics first' reading of the region (Laruelle, 2013: 7). She argues that the Federal Security Service, the military-industrial complex and President Putin prioritise security, since they see the Arctic as a platform from which Russia can assert its 'great power' status. The 'cooperation first' approach draws inspiration from an emphasis on economic opportunities and the necessity of garnering investment and gaining access to foreign expertise. Proponents of this approach include the Ministry of Natural Resources, the Ministry of Regional Development and Prime Minister Medvedev (Laruelle, 2013: 7).

One vivid example of this 'closing' of the Russian North comes from the AMEC, established by the military authorities of Norway, Russia and the USA in 1996. It focuses on spent nuclear fuel containment and remediation of radioactive pollution in the North, with particular attention to the Northern Fleet in northwest Russia and enhancing Russian capacities for handling radioactive waste. In February 2007, a key Norwegian representative within the AMEC project was denied entry to Russia on a routine work visit. The Russian MFA later stated that this representative had been engaged in illegal information gathering, even though all AMEC work had been carried out either on request or agreement from the Russian Northern Fleet and other relevant authorities (Bellona, 2007). This rejection of the AMEC representative sends a signal of changing attitudes in Russian political and security circles towards both being a recipient of 'aid' via capacity-building and the extent to which the Russian North (the military North in particular) is to be open to other actors and multilateral activities. It marks the end of the era of the more open 1990s, which should probably be understood as the exception rather than the norm (Rowe, 2015). Interestingly, however, as we shall see below, Russia continues to accept assistance relating to its environmental pollution problems. This perhaps relates to Khruscheva and Poberezhskaya's finding (2016) that environmental pollution is seen as a legacy of the Soviet Union and that therefore, I would suggest, receiving such assistance does not impinge on Russia's current self-image of a selfsufficient 'great power' state.

Finally, a fourth balancing act is between commercial and environmental concerns. The demise of the Soviet Union in 1991 left Russia with serious environmental issues, as the Soviet regime had largely failed to protect the environment from the negative consequences of industrial 
development (Rowe, 2013; Oldfield, 2005; Ostergren and Jacques, 2002). As historian Lars Rowe points out in his study of the Soviet nickel industry, environmental protection and coping with pollution were left to the same ministries that were responsible for promoting industrial development, and a deeply utilitarian view of nature prevailed (Rowe, 2013: 11-17).

This is not to say that Soviet society was devoid of concern for nature. Despite being primarily subservient to industrial concerns, the Soviet regime developed environment-monitoring infrastructure, and environmental expertise and practices (Oldfield, 2005; Bruno, 2016). The most influential and noticeable outlet for Soviet environmental interest was a movement that argued for protecting significant tracts of land from industrial development in the first place-the zapovednik system. Such a focus on 'pristine' nature was more acceptable to the Soviet leadership, in part because it upheld a division between industrialised areas and wilderness areas (Weiner, 1999).

Today, while the Russian public is concerned with environmental quality and is less willing to 'pay the costs of pollution' (Whitefield, 2003: 102; Crotty and Hall, 2012), these concerns have not been linked to significant action, and environmentalists have been relatively weak political actors throughout the post-Soviet period (Henry, 2010: 764; Yablokov, 2010). At the same time, concern for the environment is not absent and there is a growing correspondence between global and Russian approaches to discussing environmental problems. For example, President Putin's visits to high Arctic islands have often had two components. One is to visit and praise newly modernised infrastructure and feats of military derring-do (Sergunin and Konyshev, 2015), but the other is to call for the 'general clean-up' of old garbage and pollution left from the Soviet period (in Staalesen, 2016). Russian companies are also increasingly aware of their environmental obligations as part of their broader social responsibility, although issues remain on how environmental policy is implemented in practice in areas marked by ageing industrial infrastructure and weak regulatory capacity (Kelman et al., 2016).

\section{Large state, quiet voice in Arctic politics: 1997-2007}

So, how did Russia bring its post-Soviet Arctic to the Arctic Council in its first decade of existence? This section examines first Russia's participation in the Arctic Council more generally, then turns to the proposals the country made itself, and finally examines Russia's broader engagement in the areas of cooperation pushed forward by others. 


\section{Participation - small but growing}

Except for some interventions from RAIPON (which received financial support from the Canadian Government in the early days of the organisation), Russia is almost entirely absent from the official record of the Arctic Council's first three years of operation (1996-1999). The earliest recorded interventions at the Council by Russian representatives suggest a struggle to provide enough relevant actors for the various WGs and other meetings. Russian representatives repeatedly requested a greater streamlining of Arctic Council activities and meetings, and clarification of WG mandates to avoid overlap and ensure effectiveness (Arctic Council, 1999).

Russia began engaging more actively at all levels of the Arctic Council in 1999, but its representatives rarely proposed or, by extension, funded, new projects. This assertion about 1999 as a turning point is based upon a statement by an American representative during the US chairmanship, expressing 'appreciation for the expanded, vigorous Russian participation in the work of the Council' (Arctic Council, 1999). During this period, however, Russia's financial contribution remained largely in the realm of in-kind contributions of administrative and expert services.

A broad range of Russian institutions - both governmental bodies and academic institutes - were involved in the Arctic Council during its first ten years. The Ministry of Natural Resources, Roshydromet (Federal Service for Hydrometeorology and Environmental Monitoring), the Regional Development Ministry, the Ministry of Emergency Situations and the Ministry of Economic Development and Trade all sent representatives to one or more of the six WGs of the Arctic Council. The MFA supplied both the ministerial representative and the Russian SAO. In 2004, a new SAO, Vitaly Churkin, represented Russia during its 2004-2006 chairmanship period. The involvement of this experienced diplomat, who later became Russia's UN envoy, perhaps indicated that greater importance was being attached to the Council's activities, at least during the Russian chairmanship (Churkin was consistently succeeded by Ambassador-level representatives). The Russian Academy of Sciences, the Institute for Arctic and Antarctic Research, and other regional institutes participated at the WG level as well.

\section{Quiet, different proposals}

The first proposal that seems to have been actively championed by the Russian side was the National Plan of Action for the Protection of the Marine Environment from Anthropogenic Pollution in the Arctic Region of the Russian Federation (NPA-Arctic), which had actually been submitted 
and funded by the Global Environmental Fund. This proposal, concentrating on the elimination of land-based sources of marine pollution, was included in the sphere of the PAME WG and officially welcomed by the Arctic Council in the Inari Declaration (Stokke et al., 2007: 98). However, although the Russian Arctic Council representatives promoted the project extensively at Council meetings, the NPA-Arctic was never accepted as an official Arctic Council project, because of its exclusive focus on the Russian North.

In 2001, Russia began making its first proposals outside the NPAArctic, although very few of them came to fruition as projects. These years also saw some off-beat or perhaps ahead-of-their-time suggestions - such as Russia's proposing that the Arctic Council be promoted via a regular magazine comparable to the US National Geographic (Arctic Council, 2000). Likewise, in 2007, Russia presented on satellite cooperation as part of project development taking place under the Russian Federal space programme for 2006-2015. However, it seems the ground was not well prepared for such an idea. Initially, the Russian delegation had sought to bring this up in the relevant SDWG, but had missed the deadline and then sought to bring it up in plenum at an SAOs' meeting shortly thereafter. The proposed project would pinpoint the basic technical parameters for a satellite system for the Arctic region and assist across a broad range of issues including aviation, meteorological monitoring, and radio and TV broadcasting. Presenting the proposal in plenum was done with the aim of generating co-finance of the system building by interested Arctic states' (Arctic Council, 2007c).

Russia was 'thanked' for its work on the topic, but the chair noted that the proposal was presented for information only and that a formal proposal would need to be given to the SDWG within the appropriate deadline for proper preliminary handling (Arctic Council, 2007b). The idea was not brought up again at later meetings, although all the Arctic coastal states share communication and 'domain awareness' technology challenges in the High Arctic. Perhaps this was cutting it too close to the business or military interests that had initially been defined as outside the Arctic Council remit.

The most enduring feature of Russia's proposals for the Arctic Council in the 1997-2007 time period, however, is that they were aligned more closely to the sustainable development pillar over the conservation pillar at the heart of the forum (and a key framing of Arctic cross-border governance more generally; see Chapter 2). In describing the accomplishments of the Russian chairmanship, Minister of Foreign Affairs Sergey Lavrov exemplified this emphasis on people and economic development: 'While actively promoting the traditional priority environmental programs, we have sought to build up efforts in the social and economic fields. The aim was to see to it that the people in the North lived comfortably, in a 
clean natural environment and had a full-fledged access to education, social services and medical assistance' (MFA, Russia, 2006). This focus on 'people' of the North certainly relates to the fact that Russian has the most populous North, and represented a contrast to the Council's established focus on environmental problems. This differing emphasis had been a consistent feature of Russian interventions since 1999. At a November 1999 SAO meeting in Washington, DC, the then chairman of Goskomsever (the State Committee on the North), Vladimir Goman, stated that he 'would like to see projects expanded to focus on people of the North, including indigenous' (Arctic Council, 1999). At the June 2001 meeting, this focus on people was reiterated, as Russia mentioned the sustainability of life of the indigenous peoples as important, and emphasised health and housing issues. At later meetings, the focus on livelihoods (especially reindeer herding) and anything involving the 'human aspect' was stressed (SAO, 2002). This was reiterated at the close of the Russian chairmanship, with the Russian-authored October 2006 SAO report summarising that a major focus of the Russian chairmanship had been to establish a 'more balanced approach to sustainable development in the Arctic', particularly through greater focus on the Arctic peoples and the challenges facing them (SAO, 2006).

On the one hand, Russia's focus on urban people and on the specificities of the country's own northern problems resulted in project proposals that were not always embraced by the other participants in the Arctic Council. The Russian chairmanship was keen to have the Arctic Council link up with the UN urban housing programme, which focused on industrial housing and needier countries, and was, consequently, not relevant to the other less urbanised Arctic states. Although the Russian chair brought it up repeatedly, according to non-Russian interviewees, the issue was eventually dropped because of the other states' lack of interest. On the other hand, Russia's emphasis on people was substantively realised in a project on indigenous peoples and contaminants, involving the Ministry of Health, Roshydromet, the Ministry of Natural Resources and some regional governments. This project, the Persistent Toxic Substances Project, was carried out under AMAP auspices and investigated the significance of aquatic food chains as pathways of pollution exposure for indigenous peoples. Russia, via its Ministry of Health, produced new funding for the effort (SAO, 2006).

\section{Willing partner in low-political cooperation}

Participating within the norms of cross-border governance entails, for states and other actors, making not only their own proposals, but also responding to and supporting appropriately initiatives moved forward by 
others. In understanding Russia's first decade of multilateral engagement, it is useful to consider a classic division used to understand different kinds of issue areas in international governance. On the one hand, it is said that you have 'low-political' dealing with varying ebb and flow of crossborder relations. On the other hand, you have 'high-political' issues that touch on fundamental matters of peace, security and conflict for a given state. Of course, issues can change from high-political to low-political and vice versa - but the division remains usefully descriptive as long as the interest assessed is placed in its historical and broader contexts.

One example of the often rather successful 'low-politics' cooperation that was achieved under the Russian chairmanship on non-strategic issues is that of access to the Russian Arctic under the auspices of the IPY. At an October 2005 SAO meeting, Sweden expressed concern over the high tariffs charged by Russia for icebreaker services in the Northern Sea Route, even for endeavours involving scientific research for the IPY (Arctic Council, 2005). By the closing ministerial meeting in October 2006, Russian explorer Artur Chilingarov could report in his statement that icebreaker fees would be reduced by 50 per cent for IPY research activities (Chilingarov, 2006).

As cooperation moved from these coordination-style issues and into sectors of politics considered more strategic, difficulty increased. The 2007 Oil and Gas Assessment (OGA), which surveyed existing and best practices for High Arctic petroleum extraction and initially enjoyed Russian political support, exemplified how data and coordination were a struggle, for several possible reasons. Russian inability to deliver promised data for this assessment delayed the project by a year (its release had been scheduled for October 2006). While a Russian interviewee described the delay as caused by the difficulty of obtaining information from the private sector (oil and gas companies), other interviewees suggested that this information was considered secret, in that it related to the economy.

One US WG interviewee reflecting on this time period noted that, although Russia consistently sent a scientific expert as a representative, the expert seemed to struggle to pass relevant information up to the political level where permission could be gained for particular activities. For example, Russia's slow delivery of data for the PAME Arctic Marine Shipping Assessment delayed release of this assessment, although the data was ultimately provided via Finnish involvement and financing. Except for third-party financing, however, slow data collection was an issue for several countries. An interviewee commented that many countries (including the USA) had difficulties bringing the needed data for an innovative, cross-cutting marine study from multiple sources.

That Russian representatives struggled to traverse the political terrain between low- and high-political issues perhaps relates to the 
country's longstanding desire to engage in more formal negotiations and treaty-making in the Arctic, as opposed to the more diffuse fields of soft law and best practices. The Arctic Council minutes report several instances where Russian actors pointed to a need to fill 'legislative gaps and problems' at both the international and national level to underpin the various initiatives being undertaken in the Arctic region (e.g. Arctic Council, 1999). This tendency to introduce new concepts and seek internationally binding agreement is evident in two examples from the Arctic Council minutes. An ongoing interest of Russian representatives had been building international cooperation in the field of prevention and elimination of emergency situations in the Arctic. The proposal entailed establishing a network of international base points through an agreement amongst Arctic states (Arctic Council, 2004). In the end, however, participants came to the conclusion that existing treaties and conventions already provide an adequate frame for the work of the EPPR WG and that, instead, the partners should continue to develop cooperation and exchange of experience in relationship to emergency response in the Arctic (SAO, 2006). A US interviewee stated that what Russia had been proposing would entail a treaty process through which other countries were reluctant to go at that period in time. As we will see, the Russian diplomatic interest in new binding agreements absolutely characterised the Arctic Council's second decade and much of Russian leadership in Arctic cross-border governance and cooperation.

In sum, Russia's early engagement in the Arctic Council was marked by capacity issues, a preference for primarily low-political issues/coordination, an unquenched thirst for landing Arctic governance in documents and in international agreements (at a time when most states were satisfied with ongoing discussion and harmonisation of views), and a number of suggestions that did not seem to garner support because they were too closely rooted in specifically Russian Arctic issues and interests to be of interest to other countries. It may be surprising for readers of today to realise that Russia's every word was not heeded or at least carefully considered in an Arctic context. Russia in the 1990s and 2000s was widely perceived by its neighbours and the western world at large as a weakened country in 'transition' - with the ultimate end of that transition expected to be a large democratic state that looked like western states. As historian Lars Rowe suggests, western actors misread the 1990s as a new status for Russia, when the period should rather have been considered a 'state of emergency' for the Russian State, from which its leadership would seek to exit as soon as possible (Rowe, 2015). As we will see now, the second decade of the Arctic Council saw a different kind of fit between Russia's wishes and diplomatic outcomes. 


\section{High-level negotiator still receiving 'aid': 2007-2017}

In the second decade of its Arctic Council diplomacy, Russia took steps to profile itself as an Arctic leader and worked in tandem with other countries in underlining the governed, peaceful nature of the Arctic. Secondly, as is outlined below, Russia's preference for formal agreement in crossborder Arctic governance grew into a settled aspect of Arctic politics. The country often takes a leadership role in bringing these agreements to fruition. Finally, we will explore how engagement with and external financing of the amelioration of Soviet pollution sites (and more contemporary pollution issues) remained a stable feature of circumpolar cooperation across two decades of post-Cold War Arctic cooperative governance.

\section{Invigorated participation and some key differences}

Russia was supportive of and promoted the 2008 Ilullissat Declaration on the peaceful nature of the Arctic and, subsequently, the primacy and sufficiency of the coastal states in stewardship and development of the region. Russia's first Arctic policy document also came out in 2008. This short document spelt out the country's position on the Arctic as a region of peace and cooperation, while at the same time underlining the importance of Russia's pursuing its national interests, broadly defined. More specifically, this includes the centrality of Arctic extractive resources for Russia's economic future.

The pursuit of a 'positive image' in the region was specifically mentioned in the short, 2008 Arctic strategy document (Security Council, 2008). In a set of interviews carried out amongst Arctic diplomats at that time, it seemed clear that an emphasis on positive profiling - and attendant diplomatic and political follow-through - was paying dividends amongst diplomats on the 'receiving' side in the Arctic Council. A North American diplomat formulated it this way in 2012:

Since 2009, Russia has been at great pains to present that it is back as an Arctic player and has shown more Arctic leadership ... Other countries respond positively because this engagement is occurring through existing, expected vehicles like hosting conferences for discussion of issues or co-chairing initiatives, not through fighters and submarines.

(Wilson Rowe and Blakkisrud, 2014: 79)

A Norwegian diplomat made a similar observation: 'Russia is well served by international law ... Russia has geographical advantages that put it in a beneficial relationship to law of the sea and it was also 
historically and contemporarily involved in the development of this framework. Russia wants to be seen as modern and at the forefront of international law, taking the lead where they can' (Wilson Rowe and Blakkisrud, 2014: 79).

Russia's annexation of Crimea in the spring of 2014 triggered a low point in Russian-European/North American relations, and a sanctions regime against the country, including measures targeted to hinder development of Russia's Arctic energy sector (Conley and Rohloff, 2015: 2). International military and security-related cooperation was immediately frozen in the region, although low-level safety/security relations continued: for example, coast guard cooperation (Østhagen and Gastaldo, 2015). However, on the level of diplomacy and cross-border relations on non-security issues, Russia continued to engage as before, demonstrating that the region is seen as one where Russian interests are well served by continued cooperation. Russia seemingly sought to minimise spill-over effects from conflict elsewhere (see Chapter 2; and Conley and Rohloff, 2015). On a similar note, Russia's updated submission of its extended continental-shelf claim under UNCLOS in 2016 was accompanied by specific agreements concluded with both Denmark and Canada, indicating these countries' commitment to working cooperatively to settle any disputes (Government of Russia, 2015).

In other words, Russia has continued to signal a commitment to Arctic peace and demonstrate its commitment to international law in the Arctic. However, its statements have been more difficult for other Arctic states - and the broader global community - to take at face value, in light of the country's actions in Ukraine. Furthermore, Russia is still engaged in a decade-long modernisation effort in relation to its ageing Arctic military infrastructure. The resources and attention devoted to this modernisation, some of which could be used to pursue solely national interest and some of which is necessary to support a more open, more cooperative Arctic (e.g. search and rescue capacity), have also become subject to competing representations within other Arctic countries (for example, debating whether Russia's actions represent Arctic militarisation or capacity building, not unlike other countries' efforts, in preparation for a more open Arctic) (Conley and Rohloff, 2015; Pezard et al., 2017).

It is also important to note that Russia's increased engagement in Arctic issues and desire to be seen as a 'play by the rules' Arctic player was nonetheless seen to be selective, not comprehensive, even before the challenging political environment post-2014. Problems relating to openness were also reported by Canadian and Danish interviewees who noted that they had engaged in a successful exchange of information about their respective continental-shelf claims, but that it had proved 
difficult to establish similar interaction with Russia ('Russians will not share any information or data without agreement from the top'). A US civil servant also noted that the Russian north was more closed to foreign researchers than any other part of the Arctic:

Russians are not so open to scientific research permits in the Arctic as we would like. The US has never denied a permit for Arctic research, including permits to Russian researchers. I understand how this can be challenging as I also come from a large country with a large bureaucracy and interagency cooperation can be difficult, but it is a bigger problem in Russia, although there has been some improvement of late.

(Wilson Rowe and Blakkisrud, 2014: 81)

Russia's chairmanship of the work on scientific cooperation in the Arctic Council (discussed below) indicated, however, a commitment to ameliorating these problems of interagency communication. This can be seen as an attempted shift towards the 'open' end of the spectrum in Russia's ongoing balancing act between the open and closed nature of Arctic space, even at (or perhaps because of?) heightened tensions with the West on other fronts.

It is also important to note that Russia's engagement with the Council on a general level was still strongly aligned to the sustainabledevelopment side of activities, and perhaps less so on the conservation side. Russia placed more emphasis on the economic opportunities of the Arctic region than the other ministers do, with the possible exception of Norway as illustrated in Chapter 2. To take one example from Minister of Environment Donskoy's intervention at the conclusion of the Canadian chairmanship in 2015:

Russia is open to collaboration and joint implementation of large-scale projects in the Arctic, particularly in the Arctic region of the Russian Federation.

This entails not just extraction of natural resources, or energy, but also use of the Northern Sea Route as the shortest route for transportation of goods between Europe and Asia ... Climate change and technological breakthroughs make the Arctic, its wealth and resources, accessible for commercial development ... this should happen only in accordance with the highest environmental requirements and with due respect to the people living in the region and their traditional ways of life ... the cost of a failure in the fragile and unique Arctic environment is too high.

(Ministry of Environment, Russian Federation, 2015)

Both conservation and development emphases are there, but economic development occupies the driver's seat in terms of ordering and rhetorical space. 


\section{A new era of high-level negotiations}

An important feature of public diplomacy and the growing ambitions of the second decade of the Arctic Council's existence was the addition of three binding agreements on Arctic Ocean governance to the suite of best practices and soft law that work in the Council and other Arctic forums had previously generated (for more on these agreements, see Beyers, 2014; and on the most recent agreement on scientific cooperation see Hoel, 2017).

As discussed above, Russia evidenced in its first decade of post-Cold War cooperative governance a strong preference for binding agreements and legislation, and, thus, it is unsurprising that the agreements were welcomed by Russia. Russian representatives have, furthermore, played key roles in chairing all three treaty negotiation processes (cochairing with the United States and Norway). That the agreements should be binding was not necessarily the intention at the outset as Arctic Council participants began to consider the policy problems. For example, it was initially not seen as necessary that search and rescue coordination - a US proposal that enjoyed fairly immediate support (Arctic Council, 2008: 6) - be supported by formal negotiations or a binding agreement (US Delegation of the Arctic Council, 2008). On a similar note, Russia is seen to have been instrumental in promoting the pursuit of a formal agreement on the topic of marine oil preparedness and response (Rottem, 2013; Arctic Council, 2011a: 8). Russia has been highly involved in the follow-up process (oil-spill pollution prevention framework), even submitting draft framework text early in the process (Arctic Council Task Force on Arctic Marine Oil Pollution Prevention, 2014a).

Likewise, an American interviewee explained in summer 2017 that neither had there been a concrete intention that the science cooperation agreement would need to be a formal treaty. The aim of the Task Force on Scientific Cooperation was to ease the movement of people and equipment and reduce barriers to accessing research areas that are of importance and interest. The co-chair from Russia recommended that the work be extended into the US chairmanship for completion (Arctic Council, 2015a: 10). Both Russia and the US had been heavily involved, with Norway doing key work penning the draft, presenting a draft text that incorporated input from Russia, US and other delegations. At the midpoint of the Canadian chairmanship, one country pushed for a legally binding document, arguing that it would help with the movement of people and equipment across areas which 'may require significant involvement from a wide range of government agencies and stakeholders that do not have science mandates.' This country was heard and the parties pursued a legally binding agreement (Arctic Council Task Force on Scientific Cooperation in the Arctic, 2015). 


\section{Dealing with historical trash}

An interesting thread that runs throughout this second decade of the Arctic Council is that Russia continued to seek to address the contamination legacy of the Soviet Union, many times as nearly a recipient of 'development aid.' This 'client' state in transition is something that Russia decidedly shrugged off in its bilateral relations to the countries of the Nordic Arctic (Rowe, 2015). It is therefore interesting how durable this cooperation around Arctic contaminants has remained, despite Russia's reassertion of its great power and independent status, and also in light of worsened East-West relations after 2014. Even after Russia's annexation of Crimea and the sanctions regime, US-Russian cooperation under ACAP continued unabated, with the US Environmental Protection Agency even starting a new four-step project to reduce black carbon emissions in the Russian Arctic (ACAP, 2014: 4).

The ACAP WG is an extension of the work started under the AEPS. It also aims to engage in concrete amelioration of contaminated sites, as well as in legislative and regulatory changes to support this work and prevent further pollution. Importantly, AEPS was a product of the timesthe 'transitional' 1990s - in which western actors, in cooperation with many Russians themselves, saw post-Soviet Russia as ripe for reshaping into a more western mould (Rowe, 2015; Wilson, 2007b). The ACAP WG is unusual, in that its activities are focused on the Russian Arctic itself, even while being supported by a broader coalition of states. In 2007, all ACAP projects were taking place in Russia, with other countries chairing or leading efforts for work there (ACAP, 2007). Early in the 2007-2017 period, SAO meetings still remained opportunities for 'donor states' to throw their weight around. For example, at an SAO meeting in Svolvær, Norway, a Norwegian delegate highlighted that a project the country contributed to on the packaging of obsolete pesticides in the Komi Republic had recently had an issue with the pesticides being disposed of inappropriately. The ACAP chair responded that it had discussed the issue with the relevant authorities and received 'assurance that it will not reoccur' (Arctic Council, 2008: 2-3).

The work in ACAP has been marked by struggle, with Russian chairs of ACAP being particularly frustrated by and pessimistic about the small amount of progress. For example, the lack of progress on a number of projects resulted in a long report from Andrey Peshkov at the first SAO meeting of the Swedish chairmanship in Luleå (ACAP, 2011). He expressed 'frustration' with the WG and wanted to be told procedures for discontinuing some projects, including one on brominated flame retardants. He noted that there were more of these hazardous materials than ever in Russia, but that there were simply not enough resources to address the problem (Arctic Council, 2011a; ACAP, 2011). He noted 
that 'to eliminate [brominated flame retardants] in the Arctic would require comprehensive legislative frameworks and additional support from both PSI [Project Support Instrument] and governments' (Arctic Council, 2011a: 6). It also became clear that there had been no actual progress on implementing the carefully developed integrated hazardous waste management strategy (NEFCO, 2009; ACAP, 2013b), but not because the policy problem had disappeared. Reports from ACAP underlined that Russia is storing one of the 'largest stockpiles of obsolete pesticides, which in 2001 was estimated to be more than 21,000 tonnes', because the country has no option for pesticide destruction (ACAP, 2013a).

Despite a high degree of openness about the lack of forward movement and a variety of hindrances, ACAP's work precipitated the first actual funding mechanism under the auspices of the Arctic Council. While, normally, activities are funded on a programme-by-programme basis (as well as some block funding by some countries of WG secretariats and the Arctic Council secretariat), activities under ACAP have their own PSI. This funding mechanism, proposed and managed by NEFCO, had a long development period, with Arctic states initially waiting for Russia to make the first deposit (NEFCO, 2009). In 2011, pledges from other countries had been made to the PSI, and NEFCO was waiting for an agreement to be finalised with Russia on how the fund would operate at its national interface (NEFCO, 2011). By the start of the Canadian chairmanship in 2013, the pledges were in, including matching funds from Russia, but the PSI had yet to fund a project (NEFCO, 2013).

\section{Arctic governance - a social space, a malleable space}

Russia today - despite political tensions following the country's annexation of Crimea and violent interventions in Ukraine - has become a steadily more consistent and visible Arctic player in circumpolar diplomacy, fairly aligned with the regional policies and interests of the other states. However, at the beginning of the circumpolar cooperation, Russia regularly made suggestions that fell somewhat outside the remit of the Council. Has Russian diplomacy changed - or have its Arctic counterparts themselves (or their perceptions and understandings of Russia) and the Arctic Council been transformed? What does Russia's engagement in the Arctic Council tell us about the broader rules of the road in Arctic governance?

The first decade of Russia's participation in the Arctic Council was marked by three key features. First, we see issues of low capacity and also the financial constraints of Russia's first post-Soviet decade. Russian participation in WGs and Arctic Council meetings was often sponsored by other states, and these representatives were not always strongly anchored 
in the rapidly changing governance structures of Moscow. On a related note, and secondly, we also see an emphasis on low-political cooperation: for example, the coordination around reducing icebreaker fees for passage via the Northern Sea Route under activities relating to the IPY. When these lower-stakes cross-border efforts drifted closer to key strategic sectors of the economy, for example in gathering data for the Arctic Council OGA, cooperation became more complicated. Thirdly, Russia's participation increases and intensifies after the first few years of the Arctic Council. However, the activities proposed were often too closely linked to the specificities of the Russian North (urbanised, problems of industrial pollution) to appeal to a broader circumpolar audience. Another challenge was that Russia sought agreements and treaties on paper as a way of anchoring the cooperation, while most states were satisfied with a less labour-intensive and more informal discussion of best practices and harmonisation of views on policy problems.

These Russian experiences point to some of the earlier norms around procedure within the forum. These include that projects are expected to have a broader appeal than just one country's North; there is an expectation that low-political (i.e. icebreaker fees) but also more strategicrelated cooperation (i.e. sharing data around oil and gas) should be feasible; and there is also an expectation that the entire range of cooperation should be able to take place without additional layers of legal agreement or 'paperwork'.

It is important to note that Russia during this period rarely succeeded in pushing through an unpopular suggestion. This perhaps points to a taken-for-granted norm of participation - the expectation that all Arctic countries will participate in circumpolar governance (for whatever reason - interests, moral or ideological commitment). In other words, there may be a shared understanding that real 'exit' is simply not a rational/feasible option from the Arctic multilateral club. Perhaps the club nature - that if one country were to exit all other comparable countries would remain - serves to limit this option. It also points us in the direction of understanding that, of course, the norms of Arctic governance dovetail with broader norms of diplomacy and international relations. There are few countries that elect to recuse themselves from multilateral formats, even if they do not adhere to or support all of the hard- or soft-law obligations produced by that forum.

In the second decade of the Arctic Council, Russia actively profiled itself as an Arctic leader, even in the difficult cooperation atmosphere following Russia's 2014 annexation of Crimea and the western sanctions regime that came about in response. Being a legally minded, play-by-therules Arctic actor that fulfils a leadership role was a main aim for Russia. Both western and Russian interviewees at the time noted that Russia had taken a noticeably more positive direction in its role in the Arctic. This 
also suggests that a cooperative, coalition-building approach to leadership is seen as the regionally appropriate way for expressing leadership.

The second decade of the Arctic Council differs from the first primarily in new efforts directed towards creating binding agreements. This is an important development to a procedural norm from the first decade: that of minimising formality and instead working towards soft-law and bestpractice outcomes only. A number of factors could have contributed to bringing this about: for example, growing awareness of the governance challenge to be addressed in light of a rapidly warming Arctic 'icescape', as well as countering concerns, coming especially from the European Parliament, about the idea of the Arctic as an ungoverned space (Wegge, 2012). I would hazard, however, that Russian interest in such agreements may have also been an important motivating factor. As mentioned above, having legally binding agreements was a diplomatic preference for the actors representing Russia in circumpolar relations, but other countries had been sceptical (perhaps about the existence of a real governance gap or about the resources required to create such agreements). It is important to recall that the USA had originally proposed a non-binding memorandum of understanding on search and rescue, and the same non-binding format was initially considered for an agreement facilitating scientific cooperation. However, both of these areas of policy concern resulted in binding agreement. Here is an area where Russia has perhaps been a norm entrepreneur, turning the Arctic Council into a location where binding, treaty-based agreements can also be proposed and discussed (even if their formal conclusion takes place outside the Arctic Council itself). There may have been other motivating factors and driving forces, but we can at least note with more certainty that the Council's activities have changed in a preferred direction for Russia.

This relates to a second norm, which may be even more pronounced now in the Arctic Council's second decade than its first: that when the great powers awake and speak, the Council listens. It could be Russia's growing resurgence on the international stage in this time period that also shaped the country's position on the Arctic Council. As covered above, many of Russia's earlier suggestions (urban housing issues, cooperation on satellites) were seen as off-beat and deflected. Yet, just a few years later, an idea to do an archival memory project based in Russia received support. The project aimed at accumulating information and knowledge available in libraries, archives, museums and specialised collections on the circumpolar world: its history and development, its present and prospective development. When the idea was first presented the following discussion ensued:

The Chair thanked Russia and encouraged all delegations to contact their appropriate institutions to see if there is an interest in 
participating and to contact Russia for more information. Several participants applauded Russia's proposal which in the spirit of IPY would continue the sharing of information with the rest of the world. It was noted that Russia comprises the largest Arctic territory and has the largest Arctic population. There was general interest in working with Russia to develop the proposal further and to determine how best to involve the SDWG and the Arctic Council

(SDWG, 2011: 7, 8).

Interestingly, the project was a departure from previous projects (the Arctic Council does little work on cultural issues like this) and neither was it in keeping with Arctic Council procedures, in that the project focused only on Russia, despite circumpolar ambitions (SDWG, 2011).

The participants specifically referred to Russia's status as the largest geographical Arctic state and also recalled that the Russian Foreign Minister, Sergey Lavrov, had first proposed it on a visit to Tromsø (SDWG, 2009: 7). This may signal an increasing awareness of Russia's status on the global stage and certainly indicates that issues championed at a highpolitical level by Russian authorities will receive follow-up. It suggests that a norm may be emerging around an especially privileged position for 'major' Arctic countries, perhaps delimiting the room for small states to engage in the policy entrepreneurship that was so important in bringing the AEPS and Arctic Council into existence. It also suggests that any idea that garners high-level engagement from an Arctic country, be it Russia's archival memory project or Canada's desire to focus on economic issues (see Chapter 2), will receive some follow-up.

This demonstrates gradual change in norms. Russia's Arctic has always been vast - and yet Russia's voice mattered more in the latter decade than the former. This probably has to do with the growing assertiveness of Russia on the Arctic stage with Putin's second presidential period (from 2004), but also with the more committed, experienced diplomatic effort that Russia has brought to bear on the Council. As the discussion in SDAP about the archival memory project illustrates, geographical size helps - but only when a country has done the work to make it matter and where the 'rules of the road' indicate that acknowledgement of 'Arctic' power significance is possible or needed. In other words, Russia's engagements - failed and successful - with the Arctic Council do indeed illustrate that Arctic governance takes place in a highly socialised environment layered with field-specific norms. 